\title{
Exploring farmer perceptions of agroforestry via multi- objective optimisation: a test application in Eastern Panama
}

\author{
Elizabeth Gosling (1D) Esther Reith - Thomas Knoke (i) - Andrés Gerique (i) - \\ Carola Paul (1)
}

Received: 6 August 2019/Accepted: 18 June 2020/Published online: 29 June 2020

(C) The Author(s) 2020

\begin{abstract}
Understanding farmers' perceptions of and preferences towards agroforestry is essential to identify systems with the greatest likelihood of adoption to inform successful rural development projects. In this study we offer a novel approach for evaluating agroforestry systems from the farmer perspective. The approach couples rapid rural appraisal and normative optimisation techniques to determine favourable land-use compositions for meeting various socio-economic and ecological goals, based on farmers' empirical knowledge and preferences. We test our approach among smallholder farmers in
\end{abstract}

Electronic supplementary material The online version of this article (https://doi.org/10.1007/s10457-020-00519-0) contains supplementary material, which is available to authorized users.

E. Gosling $(\bowtie) \cdot$ E. Reith $\cdot$ T. Knoke

Institute of Forest Management, TUM School of Life

Sciences Weihenstephan, Technische Universität

München, Hans-Carl-von-Carlowitz-Platz 2,

85354 Freising, Germany

e-mail: elizabeth.gosling@tum.de

\section{A. Gerique}

Department of Geography, Friedrich-Alexander

University of Erlangen-Nürnberg, Wetterkreuz 15,

91058 Erlangen, Germany

C. Paul

Department of Forest Economics and Sustainable Land Use Planning, University of Göttingen, Büsgenweg 1, 37077 Göttingen, Germany
Eastern Panama, obtaining data from household interviews and using hierarchical cluster analysis to identify farm groups with similar land-use and income characteristics. We found that moderate differences in farmers' perceptions between these groups altered the type and share of agroforestry included in the optimised land-use portfolios that balance the achievement of 10 pre-selected socio-economic and ecological objectives. Such differences provide valuable information about potential acceptability of agroforestry within each group. For example, we found that farmers who derive most of their farm income from crops may be more willing to adopt silvopasture, whereas farmers who are more economically dependent on cattle may benefit from diversifying their landuse with alley cropping. We discuss the potential of this modelling approach for participatory land-use planning, especially when dealing with small sample sizes and uncertainty in datasets.

Keywords Alley cropping - Hierarchical cluster analysis · Land allocation - Participatory rural appraisal $\cdot$ Robust optimisation $\cdot$ Silvopasture

\section{Introduction}

Agroforestry has clear potential to enhance ecosystem services within agricultural landscapes of tropical 
regions (Jose 2009). However, like any agricultural innovation, farmers will only integrate trees into their farming systems if they perceive agroforestry to align with their objectives and available resources (Pannell et al. 2006). Farmers' attitudes towards agroforestry will therefore play a key role for adoption (Frey et al. 2012; Meijer et al. 2014). Understanding how farmers perceive the advantages and drawbacks of different agroforestry systems will help to identify systems that best meet farmers' needs, and to target extension activities accordingly.

Previous research into farmers' knowledge and perceptions of agroforestry has typically relied on qualitative methods (e.g. Calle et al. 2009; Frey et al. 2012; Garen et al. 2009; Hand and Tyndall 2018). Quantitative studies are less common and have been mostly limited to temperate regions (Laroche et al. 2018; Shrestha et al. 2004). Quantitative data, however, are often needed for land-use modelling approaches. These models can help analyse trade-offs between various objectives achieved by different farming and agroforestry systems, providing a powerful decision support tool for researchers, policymakers and land managers (Kaim et al. 2018; Le Gal et al. 2011). Farm level models can also serve as a discussion aid to support co-learning between researchers and farmers (Le Gal et al. 2013; Voinov and Bousquet 2010).

Our study combines positive and normative approaches to investigate farmers' perceptions of agroforestry and conventional land-use systems (Fig. 1). We obtain quantitative data from farmer interviews using a rapid rural appraisal technique in which farmers evaluated the ability of six land-uses to achieve 10 pre-defined socio-economic and ecological objectives. In the first (empiric) analysis stage we aim to understand potential differences in how distinct groups of farmers perceive agroforestry. We use hierarchical cluster analysis to group farms with similar land-use and income strategies. It is known that farm and household characteristics can influence farmers' attitudes towards agricultural innovations (Meijer et al. 2014; Pannell et al. 2006). Therefore, we are interested to compare the perceptions of each farmer group to check for potential differences in how they rated agroforestry relative to the conventional land-use systems.

Empiric ratings, however, may not be enough to understand farmers' potential land-use decisions when striving to meet multiple household goals under uncertainty. These ratings can identify the best landuse for achieving a single objective, but identifying the best mix of land-uses to achieve multiple objectives is more difficult, especially if accounting for farmers' uncertainty about the ability of each land-use to achieve each objective. This uncertainty is important, given that in regions where agroforestry is not widespread, farmers may vary considerably in their knowledge and familiarity of the systems. Therefore, empiric ratings alone may be insufficient to assess agroforestry's potential to help meet the multiple needs and constraints of heterogeneous farmer groups.

In the second stage of the analysis we therefore move to a mechanistic, multi-objective modelling approach, to investigate if agroforestry, as part of a diversified land-use portfolio, might help to reduce trade-offs between farm-level goals. Based on the land-use perceptions of each group of farmers we derive theoretically optimal land-use compositions that balance the achievement of the pre-defined socioeconomic and ecological objectives under uncertainty. This allows us to look beyond farmers' existing landuse decisions to investigate the likelihood of different farmer groups to adopt agroforestry.

Testing this approach in a forest frontier region of Eastern Panama, our research questions are:

- How do farmers with different land-use and income strategies perceive agroforestry relative to existing land-use systems?

- Will the type and share of agroforestry selected in an optimised land-use portfolio differ between farms with different land-use and income strategies?

By exploring these questions we aim to show how the coupled rapid rural appraisal and optimisation approach may help tailor policy recommendations to different groups of farmers, and to demonstrate its potential for informing group discussions in participatory planning processes. 


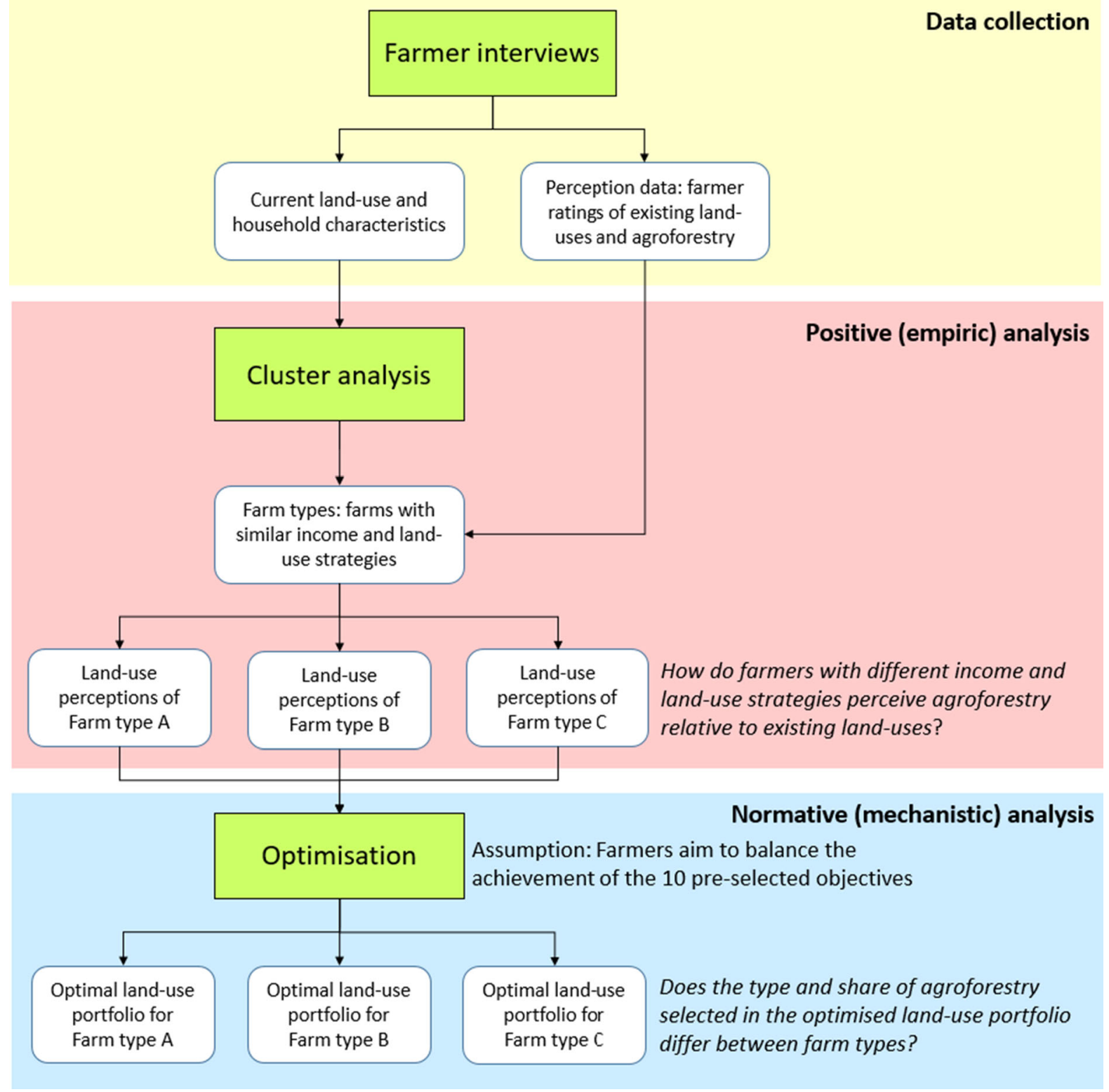

Fig. 1 Overview of research approach

\section{Methods}

Data collection

\section{Study area and sampling method}

We test our modelling approach with farmers in Tortí, a township with around 1600 inhabitants (INEC 2010) on the Pan-American Highway, around $125 \mathrm{~km}$ east of Panama City. The natural vegetation of the area is classed as humid tropical forest, with $1910 \mathrm{~mm}$ annual rainfall and a dry season from January to March (ETESA 2018). Large-scale forest clearing began five decades ago, when colonists from Panama's western provinces began to settle in the region. Pasture for cattle grazing now comprises $64 \%$ of the land-use of the wider Tortí region, with $17 \%$ forest cover, $8 \%$ cropland and 8\% fallow land (INEC 2011).

We targeted farmers using a mixed sampling method: going door-to-door in Tortí and its 
surrounding villages, approaching landholders at a local cattle auction, and asking interviewees to suggest other farmers. The interview had two parts. First we used a semi-structured questionnaire and participatory resource mapping (where farmers drew a map of their farm), to identify the current land-use composition of each farm and obtain household data. We used this data to identify groups of similar farmers via a cluster analysis. In the second part of the interview we quantified farmer opinion of different land-uses. We used this data to compare the perceptions of the different farm groups and to derive the optimised landuse portfolios for each group. The interviews took $40 \mathrm{~min}$ to $3 \mathrm{~h}$ to complete and were conducted in Spanish in April-May 2018.

\section{Selected land-uses and indicators and their rapid appraisal}

Our study quantifies farmers' perceptions of six landuses (Table 1) against 10 socio-economic and ecological indicators (Table 2). Pasture, cropland, teak plantation and natural forest represent the most common land covers in the study area. In contrast, alley cropping and silvopasture (with a tree density of $\approx 200$ trees per hectare) are not commonly practiced in Tortí: these two agroforestry systems represent innovative land-use systems for the region.

The 10 indicators against which farmers evaluated each land-use were identified from previous studies in Panama and Latin America (Table 2). They reflect different goals that farmers may consider when deciding what to produce on their farm, as well as potential benefits and drawbacks of agroforestry.

Borrowing techniques from rapid rural appraisal (Riley and Fielding 2001), we used ranking and scoring to quantify farmers' judgement of each landuse against each indicator. Before starting the evaluation task we described the land-uses with visual aids, discussing each system with the farmer to ensure a common understanding. Next we recorded farmers' general preferences by asking interviewees to rank the six land-uses from the one they like best to the one they like least (they did so by arranging six cards depicting each land-use in order of their preference). Farmers then evaluated the land-uses against the remaining indicators in two steps. First they ranked the land-uses (by arranging the cards) from best to worst for achieving a given indicator. They then scored the performance of each land-use for that indicator on a scale of $0-10$. From these individual scores, $y_{i, l, k}$, of each farmer, $k$, for each land-use, $l$, and indicator, $i$, we computed the mean score, $\hat{y}_{i, l, f}$, for the farm types, $f$, identified in the cluster analysis (described next).

Empiric analysis to identify farm types and corresponding land-use perceptions

During the interviews we asked farmers to identify all land-uses on their farm and with the help of the farm map quantify the area (in hectares) of each. We also asked farmers about their management practices (e.g. whether they use fertiliser and pesticides) and household characteristics (e.g. size of the household, sources of on-farm income). Based on this interview data we

Table 1 Description of the six land-use options, $l$, that farmers evaluated

\begin{tabular}{|c|c|c|}
\hline Land-use & Description & Source \\
\hline Cropland & $\begin{array}{l}\text { Annual or (non-woody) perennial crops, grown as a monoculture or mix of crops on the same area } \\
\text { or rotated over time }\end{array}$ & $\begin{array}{l}\text { Schuchmann } \\
\text { (2011) }\end{array}$ \\
\hline Pasture & Traditional pasture with $1.5-2$ cows per hectare & INEC (2011) \\
\hline $\begin{array}{l}\text { Alley } \\
\text { cropping }\end{array}$ & $\begin{array}{l}\text { Lines of teak grown every six meters, with rows of maize in between. Trees are grown for timber; } \\
\text { shading prevents crop growth after } 5 \text { years }\end{array}$ & Paul et al. (2017) \\
\hline Silvopasture & $\begin{array}{l}\text { Traditional pasture with a tree density of around } 200 \text { trees per hectare and stocking rate of one } \\
\text { cow per hectare. Trees are either planted or regenerate naturally (in which case they are } \\
\text { guarded) }\end{array}$ & $\begin{array}{l}\text { Montagnini et al. } \\
\text { (2013) }\end{array}$ \\
\hline Plantation & Teak plantation, trees planted with $3 \times 3 \mathrm{~m}$ spacing, harvested after 20 years & Paul et al. (2017) \\
\hline Forest & $\begin{array}{l}\text { Natural forest, can be used to collect firewood and fruits, but not for commercial timber } \\
\text { production }\end{array}$ & INEC (2011) \\
\hline
\end{tabular}


Table 2 The 10 indicators, $i$, against which farmers evaluated the six land-uses

\begin{tabular}{|c|c|c|c|}
\hline$i$ & Name & Description & Source \\
\hline 1 & $\begin{array}{l}\text { Long-term } \\
\text { income }\end{array}$ & Profit over 20 years & $\begin{array}{l}\text { Connelly and Shapiro } \\
\text { (2006) and Coomes } \\
\text { et al. (2008) }\end{array}$ \\
\hline 2 & $\begin{array}{l}\text { Labour } \\
\text { demand }^{\text {a }}\end{array}$ & Man days (per hectare) needed to manage the land-use & Tschakert et al. (2007) \\
\hline 3 & $\begin{array}{l}\text { Meeting } \\
\text { household } \\
\text { needs }\end{array}$ & The extent to which the land-use meets household needs for food and materials & $\begin{array}{l}\text { Fischer and Vasseur } \\
\text { (2002) and Tschakert } \\
\text { et al. (2007) }\end{array}$ \\
\hline 4 & $\begin{array}{l}\text { Economic } \\
\text { stability }\end{array}$ & $\begin{array}{l}\text { The extent to which economic returns of the land-use withstand the effects of } \\
\text { extreme weather, pests and diseases and price fluctuations }\end{array}$ & $\begin{array}{l}\text { Connelly and Shapiro } \\
\text { (2006) and Coomes } \\
\text { et al. (2008) }\end{array}$ \\
\hline 5 & Liquidity & $\begin{array}{l}\text { Regular cash income, including how easily the farmer can convert an investment } \\
\text { to cash when needed }\end{array}$ & $\begin{array}{l}\text { Coomes et al. (2008) and } \\
\text { Holmes et al. (2017) }\end{array}$ \\
\hline 6 & $\begin{array}{l}\text { Investment } \\
\text { costs }^{\mathrm{a}}\end{array}$ & Up-front costs of establishing the land-use & $\begin{array}{l}\text { Calle et al. (2009) and } \\
\text { Connelly and Shapiro } \\
(2006)\end{array}$ \\
\hline 7 & $\begin{array}{l}\text { Management } \\
\text { complexity }\end{array}$ & The need for special equipment, machinery, skills and knowledge & $\begin{array}{l}\text { Calle et al. (2009) and } \\
\text { Connelly and Shapiro } \\
(2006)\end{array}$ \\
\hline 8 & $\begin{array}{l}\text { Protecting } \\
\text { water supply }\end{array}$ & $\begin{array}{l}\text { The extent to which the land-use can improve the availability and quality of } \\
\text { freshwater }\end{array}$ & $\begin{array}{l}\text { Garen et al. (2009) and } \\
\text { Metzel and Montagnini } \\
\text { (2014) }\end{array}$ \\
\hline 9 & $\begin{array}{l}\text { Protecting soil } \\
\text { resources }\end{array}$ & The extent to which the land-use maintains long-term soil productivity & $\begin{array}{l}\text { Calle et al. (2009) and } \\
\text { Garen et al. (2009) }\end{array}$ \\
\hline 10 & $\begin{array}{l}\text { General } \\
\text { preferences }\end{array}$ & Farmers' preferences for each land-use option (proxy for cultural values) & $\begin{array}{l}\text { Knoke et al. (2014) and } \\
\text { Tsonkova et al. (2014) }\end{array}$ \\
\hline
\end{tabular}

'Protecting water supply' and 'protecting soil resources' are considered ecological indicators, the rest are socio-economic

andicators where lower values are more desirable ("less is better")—for all other indicators "more is better"

used hierarchical cluster analysis to identify groups of similar farms. We chose this analysis as an objective way to divide farmers into groups that may be relevant for political decision-makers. The cluster analysis included 12 variables related to farm size and ownership, current land-use and management practices, labour availability and income structure (Table 3). Sources of on-farm income included crops, cattle, timber and other processed products (e.g. honey from sugarcane). We used standardised values (z-scores) for each variable and squared Euclidean distance as the similarity measure. We chose Ward's method because of its tendency to generate homogeneous clusters that are relatively equal in size (Hair et al. 2014); this clustering algorithm is commonly used when identifying farm typologies (e.g. Köbrich et al. 2003; Nainggolan et al. 2013). Following Hair et al. (2014) we assessed the percentage changes in within- cluster heterogeneity via the agglomeration schedule, which suggested a three-cluster solution. This also allowed for a meaningful interpretation when comparing the characteristics of each cluster; we therefore decided to retain the three-cluster solution and refer to the clusters as farm types.

Based on the individual land-use scores, $y_{i, l, k}$, obtained in the farmer interviews, we computed the mean score, $\hat{y}_{i, l, f}$, for the first nine indicators for the three identified farm types, $f$, where $K$ is the total number of farmers in each group:

$$
\begin{aligned}
& \hat{y}_{i, l, f}=\frac{1}{K_{f}} \sum_{k=1}^{K_{f}} y_{i, l, k} \quad \text { for } i=1,2,3, \ldots, 9 ; \\
& \quad \text { for } f=1,2,3 . .
\end{aligned}
$$

We also computed the standard error of the mean, $S E M_{i, l, f}$, where $S D$ is the standard deviation: 
Table 3 Variables included in the cluster analysis

\begin{tabular}{|c|c|}
\hline Name & Description \\
\hline Farm area & Total area managed by the farmer (ha) \\
\hline Percent owned & Share of the farm area owned by the farmer $(\%)$ \\
\hline Percent pasture & Share of the farm area allocated to pasture $(\%)$ \\
\hline Percent crops & Share of the farm area allocated to crops $(\%)$ \\
\hline Percent plantation & Share of the farm area allocated to plantation $(\%)$ \\
\hline Main income cattle & 1 if $>50 \%$ of on-farm income comes from cattle, 0 otherwise \\
\hline Main income crops & 1 if $\geq 50 \%$ of on-farm income comes from crops, 0 otherwise \\
\hline Intensification & $\begin{array}{l}\text { Degree of land-use intensification: summed score of four bivariate variables (where } 1=\text { yes, } 0=\text { no): } \\
\text { irrigated, mechanised, uses pesticides, uses fertiliser }\end{array}$ \\
\hline Land-use diversification & Shannon diversity index of farm land-uses (Eq. S1 in supplementary material) \\
\hline $\begin{array}{l}\text { On-farm income } \\
\text { diversification }\end{array}$ & Shannon diversity index of on-farm income sources (Eq. S2 in supplementary material) \\
\hline Percent on-farm workers & Number of household members who work on the farm as a share of all household members (\%) \\
\hline $\begin{array}{l}\text { Percent household income } \\
\text { from farm }\end{array}$ & $\begin{array}{l}\text { Share of total household income generated by the farm, derived from ordinal responses: none }=0 \% \text {, a } \\
\text { small amount }=25 \% \text {, half }=50 \% \text {, most }=75 \% \text { and entire income }=100 \%\end{array}$ \\
\hline
\end{tabular}

$S E M_{i, l, f}=\frac{S D_{i, l, f}}{\sqrt{K_{f}}} \quad$ for $i=1,2,3, \ldots, 9$;

for $f=1,2,3$.

Following Knoke et al. (2014), we measured farmers' general preferences (the tenth indicator) as the number of times farmers from each farm type selected a given land-use as their first or second choice:

$\hat{y}_{10, l, f}=(\# \text { best }+\# \text { second best })_{l, f}$

The standard error of this estimate $\left(S E M_{10, l, f}\right)$ was computed within each farm type as follows (for clarity the subscript $f$, denoting farm type, has been omitted):

$$
\begin{aligned}
p_{l} & =\frac{\hat{y}_{10, l}}{\sum_{l}^{L} \hat{y}_{10, l}}=\frac{\hat{y}_{10, l}}{n} \\
S E M_{10, l} & =n \cdot \sqrt{p_{l} \cdot\left(1-p_{l}\right) / n}
\end{aligned}
$$

where $n$ is the total number of 'best' and 'second best' choices across all land-uses for each farm type, and $p_{l}$ is the relative frequency of 'best' and 'second best' choices for a given land-use within that farm type.

Normative analysis to explore the potential of agroforestry to meet farmers' objectives

We couple the farm perception data of each farm type with a normative model to investigate the role of agroforestry in theoretical land-use portfolios that minimise trade-offs between farm-level goals. These optimised land-use portfolios represent a hypothetical farm comprising various shares of the six land-uses. We use the optimisation method developed by Knoke et al. $(2015,2016)$ for land allocation problems in tropical landscapes. The model is formulated as a Min-Max (Chebyshev) problem (Romero 2001) that considers multiple objectives. In our study the 10 indicators serve as objectives, which are weighted equally in the optimisation. For each indicator we set a target level and the model selects the mix of land-uses that minimises the largest (worst) shortfall between the target and achieved level across all indicators. This results in a compromise solution that balances the achievement of all indicators. High performance in one indicator does not compensate for poor performance in another; the model instead always seeks to improve the contribution of the worst performing indicator (Romero 2001).

A strength of the modelling approach is its ability to integrate uncertainty in land-use decisions. Here uncertainty describes our lack of knowledge about how much a land-use will actually contribute to a given objective now and in the future. The model captures this uncertainty through so-called "uncertainty scenarios", which describe potential fluctuations in the performance of each land-use against each indicator. The model searches for a land-use allocation that improves the minimum performance across all 


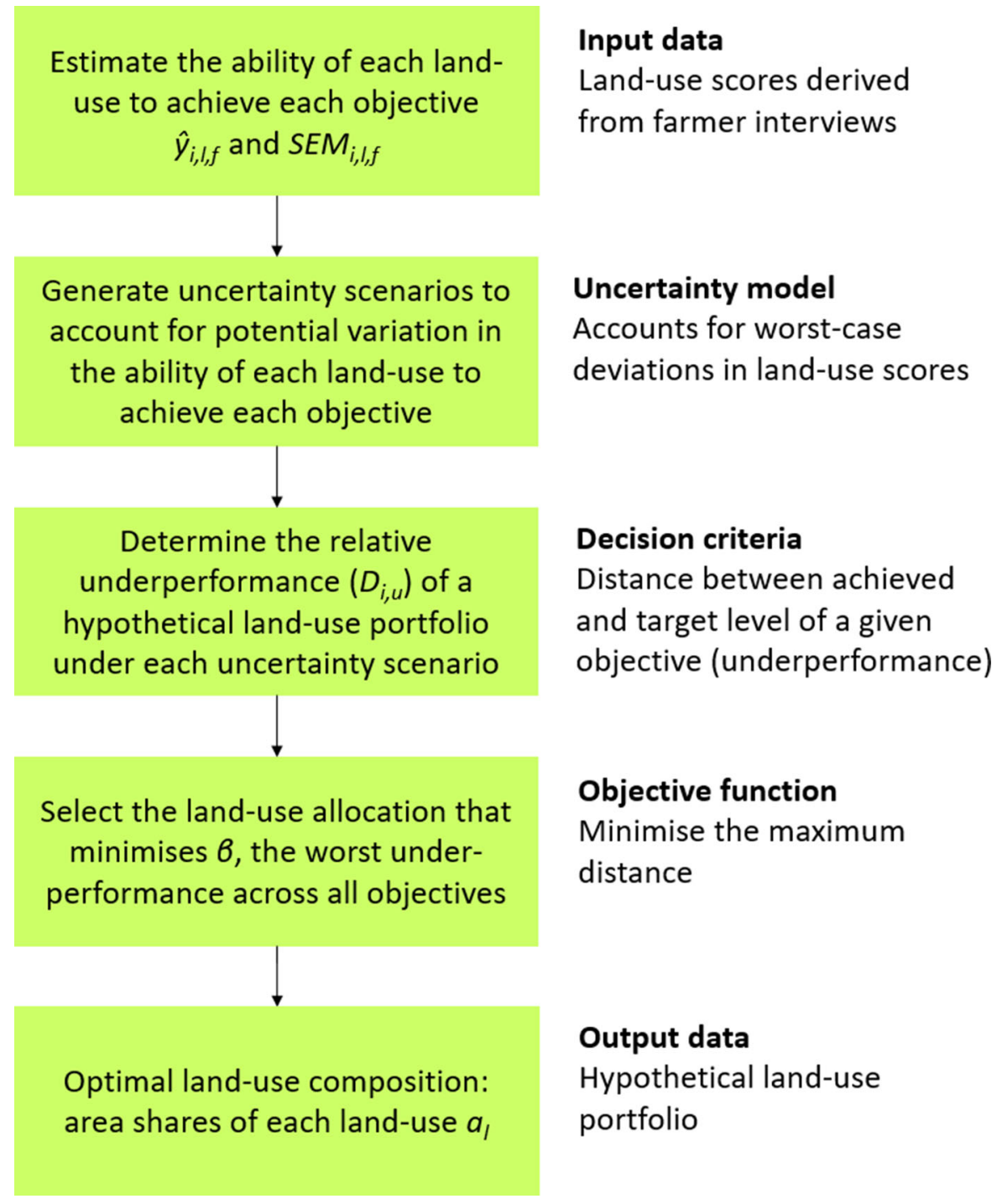

Fig. 2 Overview of the optimisation procedure

uncertainty scenarios and indicators, thereby guaranteeing a minimum performance level for each indicator even in worst-case situations. This is a form of robust decision-making, which is recommended when facing high levels of uncertainty (Walker et al. 2013). Essentially, our model simulates a risk averse decision-maker who seeks to minimise potential losses or poor performance of any indicator in worst cases (Knoke et al. 2015). Considering uncertainty promotes diversified land-use portfolios even when optimising for a single objective, because diversification provides insurance against poor performance of a single landuse for achieving that objective.

In our study we use the mean land-use scores, $\hat{y}_{i, l, f}$, derived from the interviews to estimate the ability of each land-use, $l$, to achieve each indicator, $i$, from the perspective of each farm type, $f$. To account for potential variation in these scores (and therefore in land-use performance) the model computes unwanted deviations within the uncertainty scenarios, by either 
Long-term income

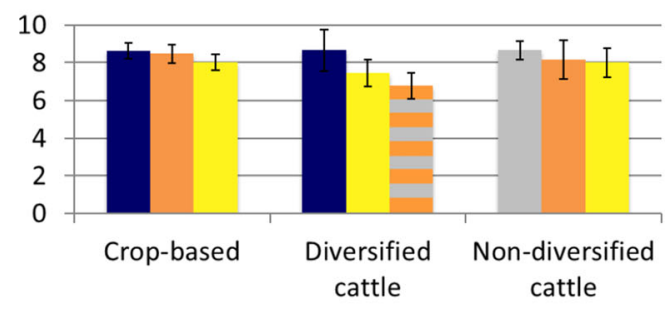

Meeting household needs

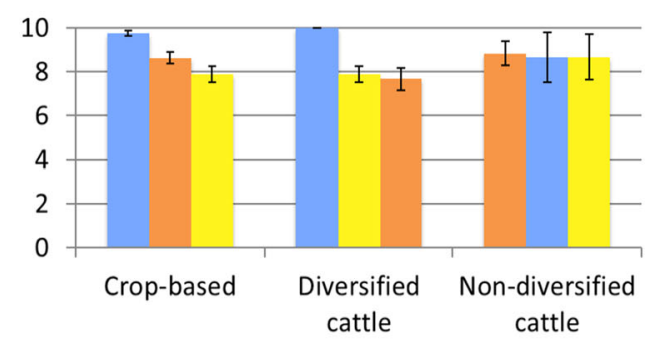

Liquidity
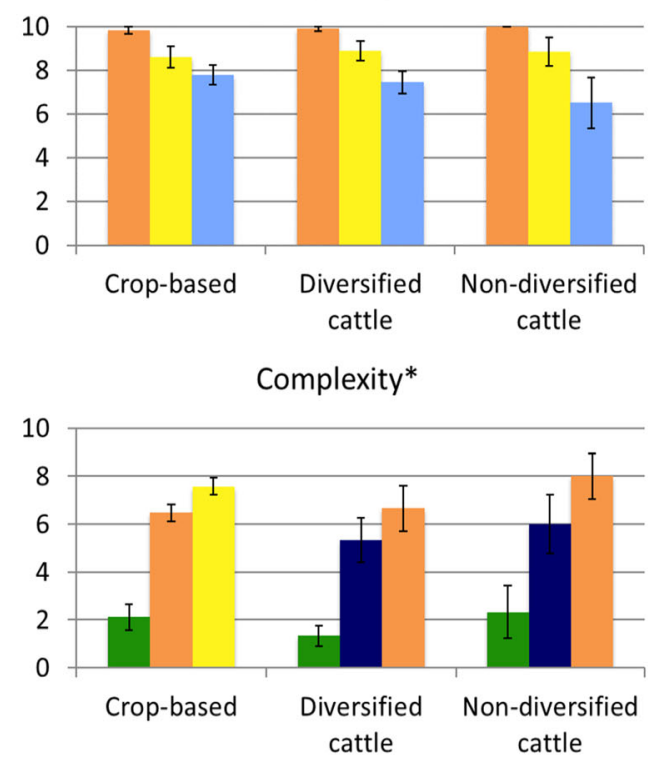

Soil

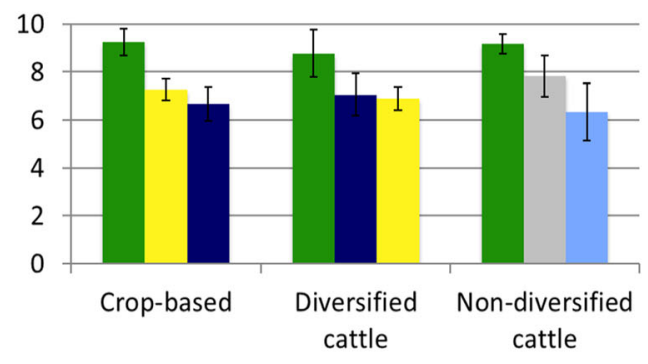

Labour demand*

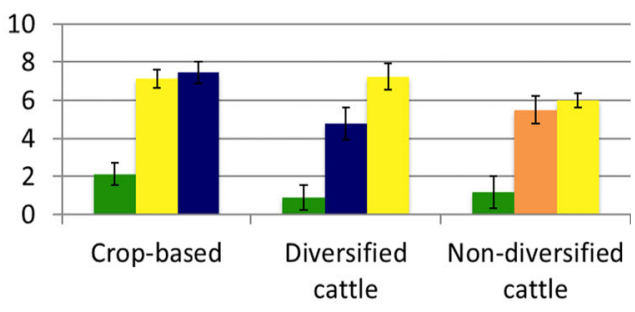

Stability

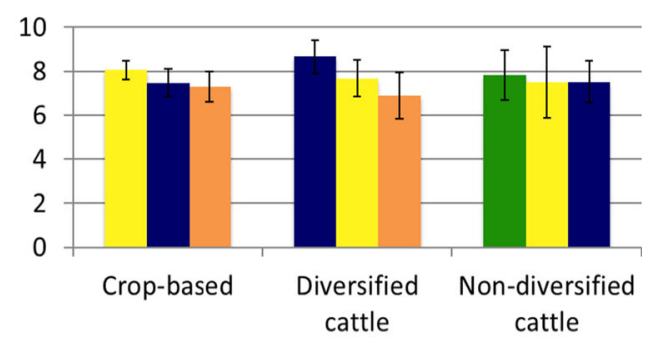

Investment Costs*

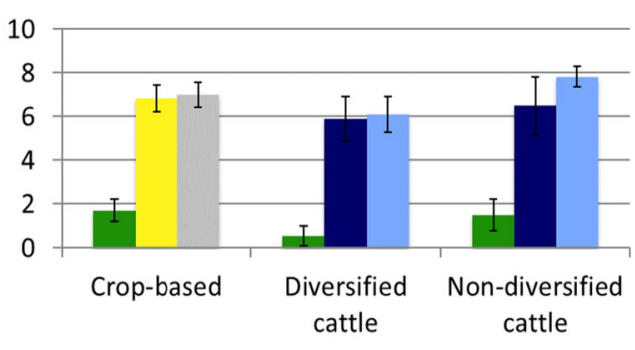

Water

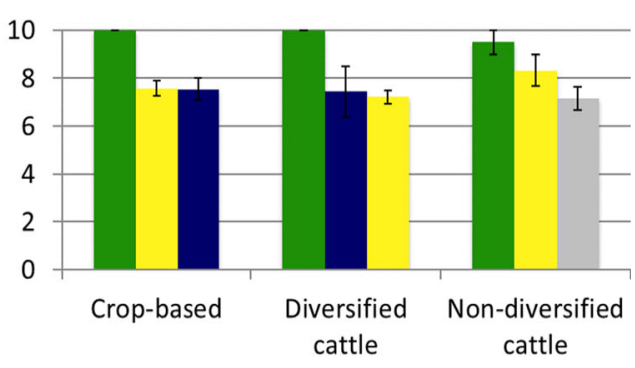

Preferences

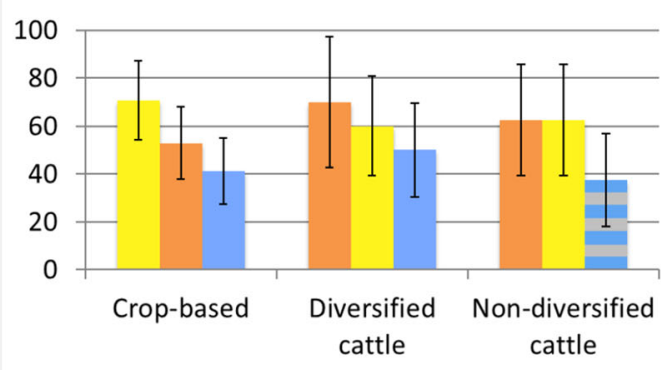

Cropland $\square$ Pasture $\square$ Alley cropping

Silvopasture

Plantation Forest 
4Fig. 3 Mean scores $\left(\hat{y}_{i, l, f}\right)$ of the three best performing landuses, $l$, for each indicator, $i$, as rated by each farm type, $f$, where $0=$ low and $10=$ high. Asterisks denote indicators where a lower score is desirable. Values for general preferences $\left(\hat{y}_{10, l, f}\right)$ are the percent of farmers who chose a given land-use as best or second best. Striped bars represent identical scores between two land-uses (both land-uses share third place). Error bars represent the $S E M_{i, l, f}$

adding or subtracting ${ }^{1}$ multiples, $f_{U}$, of the $S E M_{i, l, f}$ to or from the mean scores (Eq. S3 in the supplementary methods). Therefore our measure of uncertainty is based on variability of farmer opinion within each farm type.

We ran the optimisation separately for each farm type using the land-use scores and SEM specific to each. The model calculates the distance, $D_{i, u}$, between the target (best possible) performance level and level achieved by a hypothetical farm portfolio for each indicator in each uncertainty scenario, $u$. These distances represent underperformance. The model then selects the land-use composition (mix of the six landuses) that minimises the largest distance (worst underperformance, $\beta$ ) across all uncertainty scenarios. The optimised land-use portfolios therefore represent the land-use mix that minimises the worst underperformance of any indicator. We describe the optimisation procedure in detail in the supplementary material with an accompanying optimisation sheet (Excel file), while the main steps are summarised in Fig. 2. We also refer the reader to Knoke et al. (2020) for further details of the modelling approach.

For the main analysis we included all indicators and land-uses in the model and ran the optimisation for each farm type for $f_{U}=0,0.5,1, \ldots 3$. The factor $f_{U}$ influences the size of the unwanted deviations of landuse scores within the uncertainty scenarios, and thus dictates the level of uncertainty included in the model: $f_{U}=0$ ignores uncertainty and $f_{U}=3$ represents a high level of uncertainty (Knoke et al. 2016). Hence, optimised land-use portfolios at lower $f_{U}$ values are derived for less cautious decision-makers and the

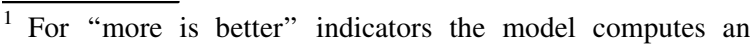
unwanted deviation by subtracting a multiple of the standard error from the mean score $\left(\hat{y}_{i, l, f}-f_{U} \times S E M_{i, l, f}\right)$, while it adds a multiple to the mean score for "less is better" indicators $\left(\hat{y}_{i, l, f}+f_{U} \times S E M_{i, l, f}\right)$.
}

portfolios at higher $f_{U}$ for more cautious decisionmakers.

We also tested different model setups as sensitivity analyses. First we excluded the two agroforestry options from the optimisation to check the plausibility of the optimised land-use portfolios (Fig. 5). We also reran the optimisation using a relative SEM for all land-use scores (Eq. S3), to better understand the effect of uneven sample sizes. Lastly, we optimised each indicator individually to help understand potential drivers and barriers to agroforestry adoption (Fig. S1).

\section{Results}

Farm types identified through the cluster analysis

We interviewed 35 farmers who managed a total area of 2681 ha; farm size ranged from five to 271 ha (mean 77 ha). All farms had similar access to markets. Based on the cluster analysis we divided our sample into three farm types with different land-use and income characteristics: 'Crop-based farms', 'Diversified cattle farms' and 'Non-diversified cattle farms' (Table 4).

Crop-based farms is the largest cluster, comprising 17 farms. Crops provide at least half of farm income for all but one of these farms. Farms in this cluster comprise more crops (mean share $45 \%$ ) and less pasture (mean share of $37 \%$ ) than the other farm types; land-use is also more diversified (mean Shannon index of 0.8 ). The diversified cattle farms are typically dominated by pasture (mean share of $83 \%$ ) and derive most, but not all, of their on-farm income from cattle. In contrast, non-diversified cattle farms obtain $100 \%$ of their on-farm income from cattle; on-farm income is therefore less diversified than for the other farm types. These farms comprise a high percentage of pasture (mean share 91\%) and are less intensified than the other farm types. A higher proportion of household members (on average 87\%) also work on the farm.

Alley cropping and silvopasture (as defined in Table 1) were not present on any of the interviewed farms. Therefore, the perceptions and opinions expressed by farmers towards these agroforestry systems represent the views of "non-adopters". A respective 76 and $45 \%$ of interviewees reported having indirect experience with silvopasture and alley 
Table 4 Comparison of the three farm types based on variables included in the cluster analysis (see Table 3)

Values represent the mean for each farm type \pm SEM. Superscript denotes significant differences $(p<0.05)$ based on oneway ANOVA with Fischer's least significant difference (LSD) test used for post hoc comparisons

\begin{tabular}{llll}
\hline & Crop-based & Diversified cattle & Non-diversified cattle \\
\hline Number of farms & 17 & 10 & 8 \\
Farm area (ha) & $81.7 \pm 10.3$ & $81.9 \pm 19.5$ & $59.1 \pm 10.8$ \\
Percent owned & $85.9 \pm 8.0$ & $90.4 \pm 8.7$ & $100 \pm 0$ \\
Percent pasture & $36.7^{\mathrm{b}} \pm 6.0$ & $83.0^{\mathrm{a}} \pm 5.0$ & $90.8^{\mathrm{a}} \pm 2.9$ \\
Percent crops & $45.1^{\mathrm{b}} \pm 7.5$ & $4.7^{\mathrm{a}} \pm 1.3$ & $0.9^{\mathrm{a}} \pm 0.5$ \\
Percent plantation & $0.2 \pm 0.2$ & $0.4 \pm 0.2$ & $0 \pm 0$ \\
Main income cattle & $0.1^{\mathrm{b}} \pm 0.3$ & $1.0^{\mathrm{a}} \pm 0$ & $1.0^{\mathrm{a}} \pm 0$ \\
Main income crops & $0.7^{\mathrm{b}} \pm 0.1$ & $0.0^{\mathrm{a}} \pm 0$ & $0.0^{\mathrm{a}} \pm 0$ \\
Intensification & $2.6^{\mathrm{a}} \pm 0.2$ & $2.2^{\mathrm{a}} \pm 0.2$ & $1.3^{\mathrm{b}} \pm 0.2$ \\
Land-use diversification & $0.8^{\mathrm{b}} \pm 0.07$ & $0.5^{\mathrm{a}} \pm 0.07$ & $0.3^{\mathrm{a}} \pm 0.08$ \\
On-farm income diversification & $0.5^{\mathrm{a}} \pm 0.05$ & $0.6^{\mathrm{a}} \pm 0.02$ & $0^{\mathrm{b}} \pm 0$ \\
Percent on-farm workers & $45.7^{\mathrm{a}} \pm 6.8$ & $37.1^{\mathrm{a}} \pm 5.3$ & $86.5^{\mathrm{b}} \pm 7.0$ \\
Percent household income from farm & $77.9 \pm 6.7$ & $82.5 \pm 5.3$ & $88.0 \pm 4.7$ \\
\hline
\end{tabular}

cropping systems similar to those included in our study, for example when visiting farms of relatives in other regions. A fifth (21\%) of farmers, however, reported no experience with either system. Therefore their assessment was based on their general experience as farmers in Tortí and our descriptions of the agroforestry systems during the farmer interviews.

Farmers' perceptions of land-uses

Figure 3 displays the land-use scores $\left(\hat{y}_{i, l, f}\right)$ of the three highest rated land-uses, $l$, for each indicator, $i$, for the three farm types, $f$. For many indicators the rankings were similar across farm types. All farm types rated pasture as the best option for maintaining liquidity, followed by silvopasture and cropland (Fig. 3). Each farm type also rated forests as the best choice for reducing labour demand, establishment costs and management complexity and for protecting soil and water resources. Finally, each group selected cropland, pasture and silvopasture as the best options for meeting household needs, and expressed strong general preferences for the two cattle-based land-uses (with crop-based farms expressing the highest preference for silvopasture).

For some indicators the rankings diverged between farm types. Each group rated a different land-use as the most stable against environmental and economic shocks: diversified cattle farms selected teak plantation, crop-based farms silvopasture and non-diversified cattle farms forest. Crop-based and diversified (a) Crop-based

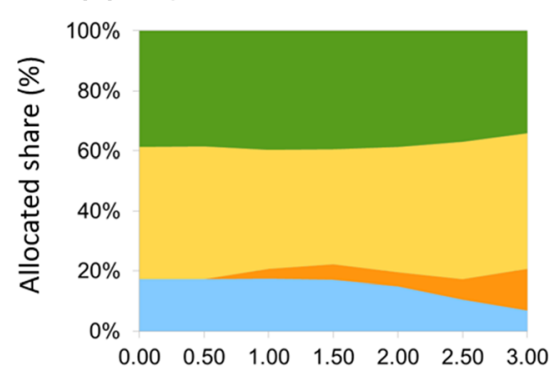

Cropland (b) Diversified cattle

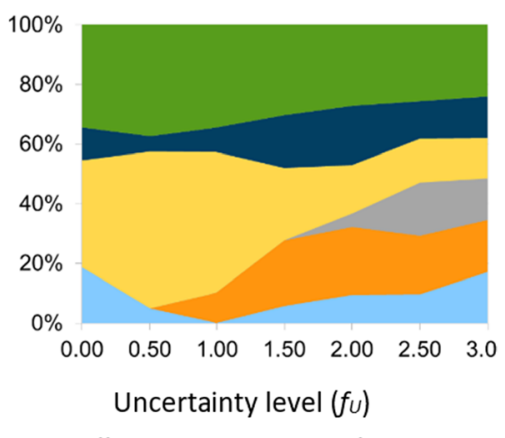

(c) Non-diversified cattle

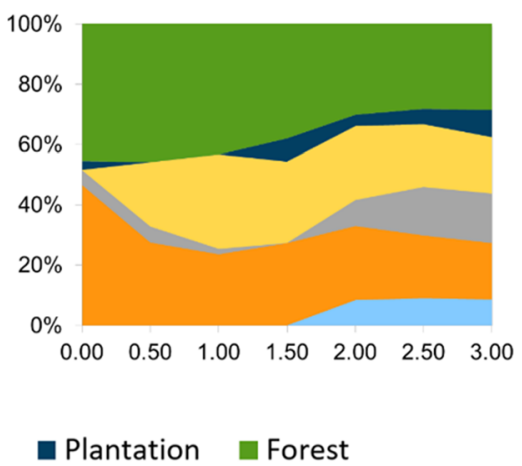

Fig. 4 Optimised farm composition (share of land allocated to each land-use) for balancing the achievement of the 10 indicators under increasing uncertainty, $f_{U}$, based on the perceptions and preferences of each farm type: a crop-based farms, $\mathbf{b}$ diversified cattle farms and $\mathbf{c}$ non-diversified cattle farms 


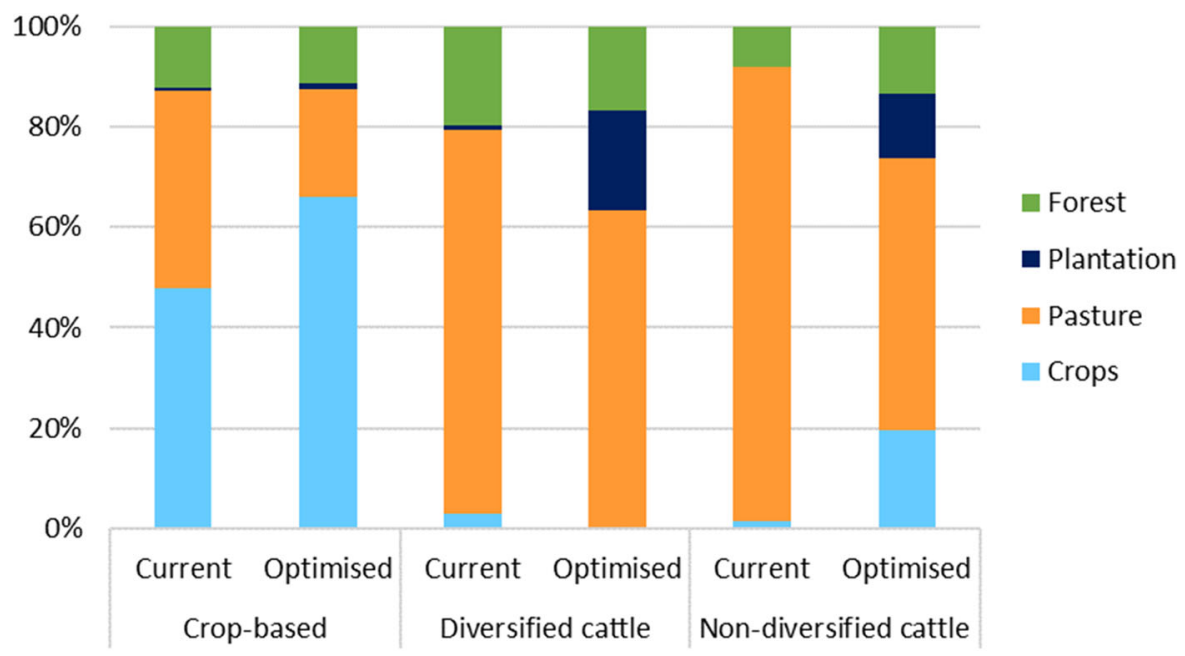

Fig. 5 Right columns: Optimised farm composition (share of land allocated to each land-use) for each farm-type for balancing the achievement of the 10 indicators under high uncertainty $\left(f_{U}=2.5\right)$ when excluding silvopasture and alley cropping from

cattle farmers rated teak plantation as the most profitable land-use, whereas non-diversified cattle farms selected alley cropping. Compared to the other farm types, the non-diversified cattle farmers perceived pasture and silvopasture to be less labour intensive, which could reflect that these farmers tended to run less intensified cattle operations with lower stocking rates. Interestingly, the crop-based farmers rated silvopasture and alley cropping more favourably for investment costs than the other farm types. This group also ranked silvopasture within the three least complex land-uses. This suggests that cropbased farmers may perceive establishment costs and management complexity to pose less of a barrier to agroforestry adoption.

Compared to silvopasture, farmers tended to express more negative opinions towards alley cropping; for five indicators each farm type ranked it in the three worst land-uses. The non-diversified cattle farmers were most positive towards alley cropping: scoring it higher for long-term income and the two ecological indicators and expressing a higher general preference. For these farmers long-term profitability and protecting soil and water resources could be important motivations to adopt the agroforestry system. However, the non-diversified cattle farmers also scored alley cropping more poorly for labour demand, management complexity and establishment costs the optimisation. Left columns: Aggregated land-use composition of farms within each farm type (recorded in the farmer interviews)

(supplementary Table S1), highlighting potential barriers to adoption for this group of farmers.

Our comparison of land-use scores between the farm types is descriptive in nature. Significant differences between farm types at the 0.05 level were found for land-use scores within the indicators labour, investment costs and complexity, as well as for longterm income for $p<0.06$ (based on one-way ANOVA with LSD post hoc comparisons-see Table S1). Our focus, however, is not on the absolute difference in land-use scores between each farm type. Instead, we want to understand differences in (a) how farmers' perceive the relative performance of agroforestry compared to the other land-use options, and (b) the variability of these perceptions (as a measure of uncertainty or risk). These relative differences are likely to be important drivers of modelled land-use decisions, but cannot be captured in a single statistical test. In the next section we show how our normative model, which accounts for the relative performance of all land-use options and their variability, allows us to analyse the possible consequences of different farmer perceptions for their simulated optimal land-use decisions.

Pairing empiric data with the normative model

Using the perceptions and preferences of each farm type, we determined the optimal land-use composition 
(a) Crop-based

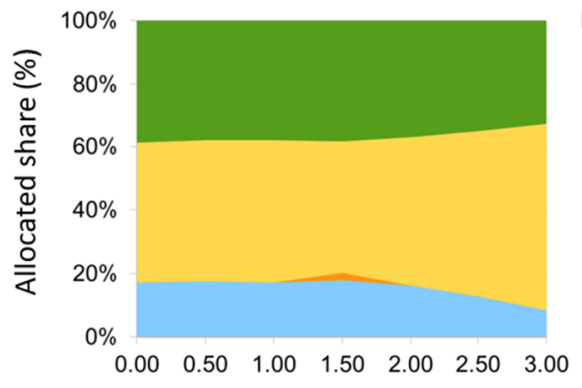

a Cropland $\quad$ Pasture (b) Diversified cattle

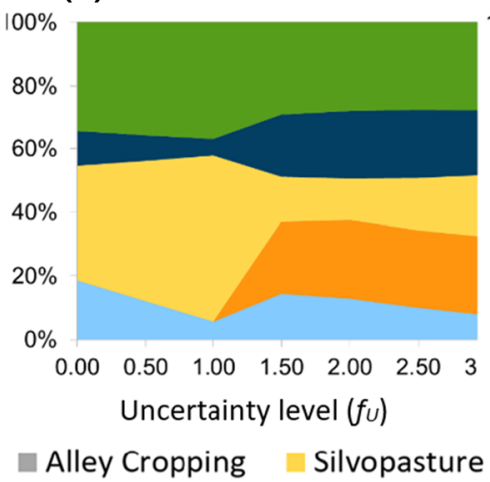

(c) Non-diversified cattle

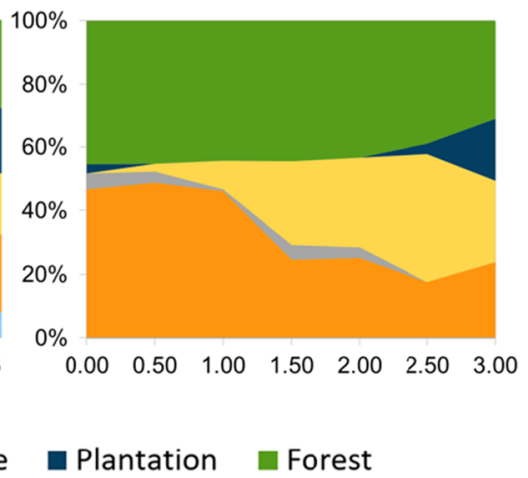

Fig. 6 Optimised farm composition (share of land allocated to each land-use) for balancing the achievement of the 10 indicators under increasing uncertainty, $f_{U}$, based on the mean land-use scores the three farm types $\left(\hat{y}_{i, l, f}\right)$ : a crop-based farms,

to balance the achievement of the 10 socio-economic and ecological indicators. While agroforestry was always selected in the optimal land-use portfolio, we found that the type and share of agroforestry included in the portfolios differed considerably between farm types (Fig. 4). Looking first at an uncertainty level of $f_{U}=2$ (representing the perspective of a more cautious decision-maker), we see that both silvopasture and alley cropping appear in the optimised portfolios of the two cattle-based farm types, but only silvopasture is present in the optimised portfolio of the crop-based farms. The overall share of agroforestry, however, was higher in the portfolio for the crop-based farms $(42 \%)$ than in the portfolios for the two cattlebased farm types (21 and 33\% respectively).

In all cases, the optimised portfolios are very different to the current land-use composition, where agroforestry is not present (Fig. 5, left bars). Excluding agroforestry from the optimisation produces landuse portfolios dominated by pasture for the cattlebased farm types, and by cropland at higher uncertainty levels for crop-based farms, with natural forest shares of $11-17 \%$ (Fig. 5, right bars). This is similar to the aggregated land-use of each farm type, although teak plantation is overrepresented in the optimised portfolios of the cattle-based farms.

Returning now to the portfolios including agroforestry, the ideal composition for the crop-based farms is quite stable across a wider range of uncertainty $\left(f_{U}=0\right.$ to $f_{U}=3$ ). In contrast, the optimised portfolios of the two cattle-based farm types become more diversified with increasing uncertainty (Fig. 4). b diversified cattle farms and c non-diversified cattle farms, using a relative standard error $\left(S E M_{i, l, f}^{\text {relative }}\right)$

This reflects the relatively large $S E M_{i, l, f}$ for these farm types. When expressed as a proportion of the mean $\left(\hat{y}_{i, l, f}\right)$, the average $S E M_{i, l, f}$ was 0.18 and 0.19 for the diversified and non-diversified cattle farms, compared to 0.12 for the crop-based farms. In our model, increasingly equal land-use shares at higher values of $f_{U}$ is the result of a statistical averaging effect to buffer against uncertainty (Knoke et al. 2016). Higher $f_{U}$ values enlarge the unfavourable deviations in land-use performance considered in the uncertainty scenarios (Eq. S3), and the model selects a more diversified land-use portfolio to protect against potential underachievement of a given indicator. A high $S E M_{i, l, f}$ enhances this effect, and hence the trend towards greater diversification at higher uncertainty levels is more pronounced in the optimised portfolios of the two cattle-based farm types.

The differences in the type and share of agroforestry included in the optimal portfolios may therefore relate to (a) differences in farmers' perceptions of the land-uses, or (b) diversification effects driven by the smaller sample size and relatively large $S E M_{i, l, f}$ for the cattle-based farms. To check that our results were not predominantly driven by differences in the sample sizes, we reran the optimisation for each farm type, using the same land-use scores $\hat{y}_{i, l, f}$, but a relative standard error, $S E M_{i, l, f}^{\text {relative }}$, derived from the $S E M_{i, l}$ of all farms combined, which on average was $10 \%$ of the mean land-use scores (Eq. S12). This ensured that the size of the standard error as a 
proportion of the mean land-use score remained constant between farm types.

Using a relative standard error led to minimal changes in the optimal land-use portfolio for the cropbased farms (compare Fig. 4a and 6a). Using the $S E M_{i, l, f}^{\text {relative }}$ did, however, alter the ideal portfolios of the two cattle-based farm types; both became less diversified. For instance, alley cropping no longer appears in the optimal land-use portfolio of the diversified cattle farms under high uncertainty levels (compare Fig. 4b and 6b). Similarly, teak plantation and cropland are no longer included in the optimal portfolio of non-diversified cattle farms at moderatelyhigh uncertainty levels, and the share of alley cropping reduces by five percentage points.

Nevertheless, after adjusting the standard error, differences remain in the type and share of agroforestry included in the optimal land-use portfolios of each farm type. The portfolio for crop-based farms still contains the largest share of agroforestry (e.g. $47 \%$ at $f_{U}=2$ ) and the portfolio for diversified cattle farms the smallest ( $13 \%$ at $f_{U}=2$ ). Alley cropping is only included in the optimal portfolio of the nondiversified cattle farms. This demonstrates that the selection of agroforestry systems is not only driven by diversification effects from small samples.

Portfolios optimised for individual objectives (Fig. S1) help to understand factors that may promote or hinder agroforestry adoption. We found that agroforestry was only selected in optimised portfolios for a small set of indicators (long-term income, household needs, economic stability and general preferences), which diverged strongly between farm types. For crop-based farms, agroforestry only appears in the optimised portfolios for economic stability and general preferences, where silvopasture comprises more than $70 \%$ of the land-use. The perceived superior performance of silvopasture for these two indicators contributes to its dominance in the multi-indicator portfolio for crop-based farms, i.e. in the portfolio that consider all 10 objectives simultaneously. For the cattle-based farm types, silvopasture appears in lower shares $(<37 \%)$ in portfolios optimised for these two indicators, as well as in the portfolio optimised for long-term income for the diversified farms and in the portfolio optimised for meeting household needs for the non-diversified farms. Alley cropping is also selected for two indicators for the non-diversified cattle farms; it dominates ( $90 \%$ share) the portfolio optimised for long-term income and contributes $14 \%$ to the general preference portfolio. The favourable rating for long-term income (and to a lesser extent general preferences) is therefore likely to contribute to the selection of alley cropping in the multi-indicator portfolio of non-diversified cattle farmers.

Importantly, the inclusion of agroforestry (predominately silvopasture) within the general preference portfolio of each farm type suggests that the farmers' cultural preferences are compatible with (rather than posing a barrier to) agroforestry adoption. Similarly, the inclusion of silvopasture in the optimal portfolio for economic stability suggests that this indicator could be a potential driver of agroforestry adoption across all farm types.

Agroforestry was not selected in portfolios optimised for the remaining six indicators. These portfolios were very similar across the farm types, dominated by either pasture (for maintaining liquidity) or forest (for reducing labour demand, investment costs and management complexity, and protecting soil and water resources). The superior performance of forest for the latter indicators explains its consistently large share in the multi-indicator portfolios for each farm type. The absence of agroforestry in singleindicator portfolios suggest that these indicators may represent barriers to agroforestry adoption.

\section{Discussion}

Insights from the empiric and normative approaches

Within our sample we found only moderate differences in farmers' perceptions of the two agroforestry systems. Across all farm types, farmers tended to evaluate silvopasture more favourably than alley cropping against the 10 indicators. This aligns with the 'cattle culture' of pioneer areas in Central and South America, where owning cattle awards prestigious social status. Cattle also represent a way of accumulating wealth as a form of private insurance, which is especially important in regions with weak healthcare, loan and pension systems (Connelly and Shapiro 2006; Perz et al. 2006). Empiric rankings suggest differences in how the farm types perceived agroforestry in terms of investment costs, 
management complexity and long-term profitability, as well as in their general preferences towards the systems. Although based on a limited dataset, our findings represent a new contribution to agroforestry research, because previous studies on farmers' perceptions have not compared the views of farmers with different land-use and income characteristics (e.g. Frey et al. 2012; Garen et al. 2009; Hand and Tyndall 2018). The ranking of mutually exclusive land-use options alone, however, often does not reflect the farmer's reality. Decisions are usually taken at the farm level, including multiple land-use options that serve multiple needs of the farm/household. These complexities can hardly be incorporated into empiric rankings, but they may constitute important barriers to agroforestry adoption. Our approach therefore couples empiric data with farm-level optimisation, capable of considering uncertainty as well as multiple land-use options and farm-level objectives simultaneously.

Despite the moderate difference in the perception data of the empiric analysis, we found substantial differences in the type and share of agroforestry selected in the optimised land-use compositions of each farm type. This reveals that an overall positive ranking of agroforestry may alone be a misleading indicator of farmers' acceptance of agroforestry, if farm-level considerations are not sufficiently accounted for. Here, optimisation approaches may be a helpful methodological complement. Assuming that farmers strive to reduce underperformance of the 10 pre-selected indicators, the optimal portfolios suggest that crop-based farms would benefit from allocating a larger share of their land to silvopasture, while for cattle-based farms diversifying their farm with more land-uses (including alley cropping) may be advantageous. Differences in the optimal portfolios of farms with similar land-use and income patterns are plausible, given the many empiric studies that link farm and household characteristics with farmers' land-use decisions, including the degree of agricultural diversification (Ochoa et al. 2019; Torres et al. 2018), and adoption of agroforestry (Pattanayak et al. 2003; Zabala et al. 2013).

Differences in the optimised land-use portfolios provide us with important information, because it suggests that farmers belonging to each farm type may respond differently to agroforestry. Understanding these differences may help to design better policies to achieve agroforestry adoption by tailoring recommendations and extension programs to different groups of farmers (Köbrich et al. 2003). For our study region, agricultural extension staff could emphasise the long-term profitability of alley cropping systems (as evidenced by bio-economic modelling by Paul et al. (2017) based on local trials) when working with farmers with diversified farm income sources. We also found that farmers who derive most of their farm income from cattle may perceive management complexity and investment costs as a greater barrier to agroforestry adoption. Promoting agroforestry among these farmers may benefit, for example, from skillsharing and training programs to enhance farmers' capacity to manage the systems, as well as financial incentives (e.g. subsidising the cost of tree seedlings and fencing material) to reduce up-front capital costs.

Critical appraisal of the modelling approach

The normative approach allows us to go beyond current land-use patterns to explore the potential of agroforestry to be part of diversified farm portfolios that meet multiple farm-level goals. Divergence between the optimised and existing land-use portfolios may signal a conflict between the land-use practices that farmers wish to have, and those that they can implement given their available resources and household needs. For example, the optimal portfolios derived from farmers' stated land-use preferences all contain agroforestry although it was absent on their own farms. To more realistically capture individual farm constraints within the optimised portfolios, it might be necessary to include calculated economic indicators in the optimisation. Such indicators could be derived from more intensive farm surveys, for example to determine expected costs and cash flows to better reflect hard economic constraints not reflected in farmer preferences. Other studies in Eastern Panama have also suggested a conflict between the forest-friendly farming practices that farmers deem desirable and those that are possible with their economic constraints (Tschakert et al. 2007). Our modelling approach revealed that individual goals such as reducing investment costs and management complexity as well as maintaining liquidity may impede agroforestry adoption. However, the approach also shows that diversified land-use portfolios can help buffer these constraints. For example, leaving land as forest can reduce overall investment costs and 
management complexity of a farm portfolio, while the inclusion of pasture helps maintain liquidity. This speaks for promoting agroforestry not as a stand alone land-use option, but as a potential complement to other land-use systems as part of a diversified farm portfolio.

The optimal farm compositions derived from our modelling approach assumes that the 10 socio-economic and ecological objectives are equally important for farmers' decision-making. While this is unlikely to be the case for an individual farmer, the assumption is appropriate for modelling the decision-making of a whole group of farmers, whose individual preferences and constraints are uncertain. This is a situation policy-makers often face. We account for potential variation in farmers' priorities by including a broader set of plausible objectives in the optimisation, which we weigh equally. The similarity between the existing and optimised land-use portfolios when excluding agroforestry vouches for the plausibility of model results, supporting our decision to weigh objectives equally.

Despite its normative nature, we found the model allows for a plausible representation of land-use trends, which Knoke et al. (2020) also demonstrated in a recent Ecuadorian case study. For instance, the expansion of forest cover in the optimised portfolios relative to the existing forest cover in our study area is consistent with forest transition theory, which has already been observed in Panama (Wright and Samaniego 2008). We also obtained more diversified land-use portfolios at higher levels of uncertainty, consistent with other applications of the model in Latin America (Knoke et al. 2016; Uhde et al. 2017). Finally, we obtained more diversified land compositions when considering multiple criteria in the optimisation compared to a single objective only, a trend which van der Plas et al. (2016) have shown empirically at the landscape scale.

We recognise that our results stem from a small dataset, where not all farmers had prior knowledge of the agroforestry systems in question. We tried to ensure a common understanding among all farmers by discussing each land-use before starting the evaluation task, but some farmer responses may still be "guesstimates". Other authors promote similar ranking and scoring methods for collecting high quality data from local people (Mayoux and Chambers 2005; Riley and Fielding 2001), but we also acknowledge the inherent uncertainty around the degree to which data accurately and consistently capture farmers' opinions (Gosling and Reith 2019). This, however, highlights a strength of our modelling approach which actively integrates uncertainty around farmer judgement and preferences in the optimisation. The measure of uncertainty used in the model $\left(S E M_{i, l, f}\right)$ reflects variation in farmer opinion. We would expect this variation to increase when farmers are less sure of their responses, but also when sample sizes are small (Eqs. 2 and 4). The model accounts for this potential variation via the uncertainty scenarios, searching for solutions that are satisfactory for a wide range of land-use scores (Knoke et al. 2016). This results in a land-use composition that caters for a range of farmer opinions, and hence should be acceptable to all farmers comprising a farm type. Nevertheless, if sample sizes are too small (or reliability of the data too poor) the strong diversification effects resulting from high standard errors may mask potential differences between groups. We addressed this issue by using a relative standard error, but future research could investigate minimum sample sizes needed to achieve stable land-use portfolios.

\section{Potential applications}

Our data collection method represents a rapid appraisal tool (Riley and Fielding 2001), and when faced with small or uncertain datasets the model actively accounts for potential variation in farmer opinion. We therefore see it as a pragmatic approach to guide land-use planning and agroforestry policy decisions in regions where it may not be possible to carry out large-scale household surveys. In this context the optimisation approach is not designed to prescribe exact "ideal" farm compositions to be implemented by different groups of farmers, but instead to explore the conditions under which agroforestry might be a desirable complement to meet farmers' goals.

As an example application, practitioners could use our survey method to capture farmers' knowledge and perceptions of agroforestry during the development of incentive schemes and extension programs. We used cluster analysis to identify farms with similar land-use and income patterns, but farmers could also be grouped using much simpler methods (e.g. based on farm size, income level or the main farm enterprise). Understanding if and how perceptions deviate between different farmer groups could help policy- 
makers to prioritise further data collection and farmer collaboration. For instance, the inclusion of agroforestry systems in the optimal portfolio of a particular group of farmers suggests that the systems could be of interest to those farmers. More data could then be collected from such groups to better understand their constraints and the support needed to adopt agroforestry.

Our modelling approach could also be relevant for participatory land-use planning as a discussion tool to support strategic thinking about sustainable land-use compositions (Le Gal et al. 2013). Stakeholders could evaluate the pros and cons of different land-use compositions and generate a range of solutions by modifying the importance (weight) placed on each objective (Stewart et al. 2004). Ezquerro et al. (2019), for example, have shown how a similar modelling method can be used for stakeholder interaction in forest management. Our model is well suited to user interaction because it works off-line with open source software and short calculation times (for our problem less than $2 \mathrm{~s}$ per optimisation). This makes it possible to re-run the optimisation with altered parameters in situ, to facilitate a co-learning feedback loop between the researcher and farmer. In such a process the approach could be extended by including individual farm constraints that are not yet captured in the optimisation model.

Finally, the optimisation method can easily accommodate diverse data types, including measured, modelled and interview data (Knoke et al. 2016; Uhde et al. 2017). This creates an opportunity to bring together different sources of knowledge in land-use planning. For example, farmers' experienced-based knowledge (Turnhout et al.2012), could be coupled with scientific data on ecological functions of different systems, such as their contribution to biodiversity and other ecosystem services. An optimisation incorporating these different perspectives could determine the ideal landuse composition at the landscape level. Such an approach could be used to investigate the role of agroforestry in multi-functional landscapes that enhance ecosystem services while accounting for farmers' needs and preferences.

\section{Conclusions}

By coupling empiric interview data of farmers in Eastern Panama with a mechanistic optimisation model, we demonstrate a new approach for investigating the potential of agroforestry to meet the multiple needs of different groups of farmers. We found that the type and share of agroforestry included in theoretically optimal land-use portfolios differed for farms with different land-use and income characteristics. Such differences can provide valuable information about the possible acceptability of different agroforestry systems among different groups of farmers. In our case study, for example, we found that farmers who derive most of their farm income from crops may be more willing to adopt silvopasture, whereas farmers who are more economically dependent on cattle may benefit from diversifying their landuse with alley cropping. We found that in our study region agroforestry (especially silvopasture) does not appear to conflict with farmers' general land-use preferences, but divergence between the optimal and current land-use portfolios suggest that hidden constraints not reflected in these preferences may hinder agroforestry adoption. Single-objective optimisations reveal that aspects such as reducing investment costs and management complexity and the need to maintain liquidity may be among these constraints. This speaks for the importance of promoting agroforestry as part of a diversified land-use portfolio to help buffer farmlevel constraints. Such insights were revealed with comparably low measurement effort, and thus the coupled empiric-normative approach may be an important starting point for policy-makers and scientists to set priorities for follow-up research on policy design. We test the modelling approach in Eastern Panama, but think it could be easily transferred to other regions to better understand the socio-economic conditions under which agroforestry may be a desirable land-use alternative to meet farmers' needs.

Acknowledgements Open Access funding provided by Projekt DEAL. This work was supported by the German Research Foundation (DFG) - Grant PA 3162/1. We are very grateful to Rodrigo Duarte, Peter Glatzle and Alyna Reyes for their assistance with the farmer interviews, and warmly thank the farmers in Tortí who shared their knowledge and experience with us. 


\section{Compliance with ethical standards}

Conflict of interest The authors declare that they have no conflict of interest.

Ethical standard The research complies with ethical standards for research involving human participants, including obtaining informed consent from all interviewees.

Open Access This article is licensed under a Creative Commons Attribution 4.0 International License, which permits use, sharing, adaptation, distribution and reproduction in any medium or format, as long as you give appropriate credit to the original author(s) and the source, provide a link to the Creative Commons licence, and indicate if changes were made. The images or other third party material in this article are included in the article's Creative Commons licence, unless indicated otherwise in a credit line to the material. If material is not included in the article's Creative Commons licence and your intended use is not permitted by statutory regulation or exceeds the permitted use, you will need to obtain permission directly from the copyright holder. To view a copy of this licence, visit http://creativecommons.org/licenses/by/4.0/.

\section{References}

Calle A, Montagnini F, Zuluaga AF (2009) Farmer's perceptions of silvopastoral system promotion in Quindío, Colombia. Bois For Trop 300:79-94

Connelly A, Shapiro EN (2006) Smallholder agricultural expansion in La Amistad Biosphere Reserve. J Sustain For 22:115-141. https://doi.org/10.1300/J091v22n01_07

Coomes OT, Grimard F, Potvin C, Sima P (2008) The fate of the tropical forest: carbon or cattle? Ecol Econ 65:207-212. https://doi.org/10.1016/j.ecolecon.2007.12.028

Empresa de Transmisión Eléctrica, ETESA (2018) Historical data on mean annual rainfall in Tortí (1977-2018). www. hidromet.com.pa/clima_historicos.php. Accessed 20 Nov 2018

Ezquerro M, Pardos M, Diaz-Balteiro L (2019) Integrating variable retention systems into strategic forest management to deal with conservation biodiversity objectives. For Ecol Manag 433:585-593. https://doi.org/10.1016/j. foreco.2018.11.003

Fischer A, Vasseur L (2002) Smallholder perceptions of agroforestry projects in Panama. Agrofor Syst 54:103-113. https://doi.org/10.1023/A:1015047404867

Frey GE, Fassola HE, Pachas AN, Colcombet L, Lacorte SM, Pérez O, Renkow M, Warren ST, Cubbage FW (2012) Perceptions of silvopasture systems among adopters in northeast Argentina. Agric Syst 105:21-32. https://doi.org/ 10.1016/j.agsy.2011.09.001

Garen EJ, Saltonstall K, Slusser JL, Mathias S, Ashton MS, Hall JS (2009) An evaluation of farmers' experiences planting native trees in rural Panama: implications for reforestation with native species in agricultural landscapes. Agrofor Syst 76:219-236. https://doi.org/10.1007/s10457-009-9203-4
Gosling E, Reith E (2019) Capturing farmers' knowledge: testing the analytic hierarchy process and a ranking and scoring method. Soc Nat Resour 17:1-9. https://doi.org/10. 1080/08941920.2019.1681569

Hair JF, Black WC, Babin BJ, Anderson RE (2014) Multivariate data analysis, 7th ed., new internat. ed.

Hand A, Tyndall J (2018) A qualitative investigation of farmer and rancher perceptions of trees and woody biomass production on marginal agricultural land. Forests 9:724. https://doi.org/10.3390/f9110724

Holmes I, Potvin C, Coomes O (2017) Early REDD + implementation: the journey of an indigenous community in Eastern Panama. Forests 8:67. https://doi.org/10.3390/ f8030067

INEC (2011) Censo Nacional Agropecuario 2010, VIII Tenencia y Aprovechamiento de la Tierra. Explotaciones. https:// www.contraloria.gob.pa/inec/Publicaciones/subcategoria. aspx?ID_CATEGORIA=15\&ID_SUBCATEGORIA= 60\&ID_IDIOMA=1ID_SUBCATEGORIA $=60 \&$ ID_ PUBLICACION=470\&ID_IDIOMA=1\&ID_ CATEGORIA $=15$. Accessed 20 Nov 2018

Instituto Nacional de Estadística y Censo, INEC (2010) XI Censo Nacional de Población y VII de Vivienda 2010: Volumen I: Lugares Poblados de la República: 2010. http://www.contraloria.gob.pa/inec/Publicaciones/ Publicaciones.aspx?ID_SUBCATEGORIA=59\&ID_ PUBLICACION=355\&ID_IDIOMA=1\&ID_ CATEGORIA=13. Accessed 11 Mar 2019

Jose S (2009) Agroforestry for ecosystem services and environmental benefits: an overview. Agrofor Syst 76:1-10. https://doi.org/10.1007/s10457-009-9229-7

Kaim A, Cord AF, Volk M (2018) A review of multi-criteria optimization techniques for agricultural land use allocation. Environ Model Softw 105:79-93. https://doi.org/10. 1016/j.envsoft.2018.03.031

Knoke T, Bendix J, Pohle P, Hamer U, Hildebrandt P, Roos K, Gerique A, Sandoval ML, Breuer L, Tischer A et al (2014) Afforestation or intense pasturing improve the ecological and economic value of abandoned tropical farmlands. Nat Commun 5:5612. https://doi.org/10.1038/ncomms6612

Knoke T, Paul C, Härtl F, Castro LM, Calvas B, Hildebrandt P (2015) Optimizing agricultural land-use portfolios with scarce data-a non-stochastic model. Ecol Econ 120:250-259. https://doi.org/10.1016/j.ecolecon.2015.10. 021

Knoke T, Paul C, Hildebrandt P, Calvas B, Castro LM, Härtl F, Döllerer M, Hamer U, Windhorst D, Wiersma YF et al (2016) Compositional diversity of rehabilitated tropical lands supports multiple ecosystem services and buffers uncertainties. Nat Commun 7:11877. https://doi.org/10. 1038/ncomms 11877

Knoke T, Paul C, Rammig A, Gosling E, Hildebrandt P, Härtl F, Peters T, Richter M, Diertl K-H, Castro LM et al (2020) Accounting for multiple ecosystem services in a simulation of land-use decisions: does it reduce tropical deforestation? Glob Change Biol. https://doi.org/10.1111/gcb.15003

Köbrich C, Rehman T, Khan M (2003) Typification of farming systems for constructing representative farm models: two illustrations of the application of multi-variate analyses in Chile and Pakistan. Agric Syst 76:141-157. https://doi.org/ 10.1016/S0308-521X(02)00013-6 
Laroche G, Domon G, Gélinas N, Doyon M, Olivier A (2018) Integrating agroforestry intercropping systems in contrasted agricultural landscapes: a SWOT-AHP analysis of stakeholders' perceptions. Agrofor Syst 27:93. https://doi. org/10.1007/s10457-018-0191-0

Le Gal P-Y, Dugué P, Faure G, Novak S (2011) How does research address the design of innovative agricultural production systems at the farm level?: a review. Agric Syst 104:714-728. https://doi.org/10.1016/j.agsy.2011.07.007

Le Gal P-Y, Bernard J, Moulin C-H (2013) Supporting strategic thinking of smallholder dairy farmers using a whole farm simulation tool. Trop Anim Health Prod 45:1119-1129. https://doi.org/10.1007/s11250-012-0335-6

Mayoux L, Chambers R (2005) Reversing the paradigm: quantification, participatory methods and pro-poor impact assessment. J Int Dev 17:271-298. https://doi.org/10.1002/ jid. 1214

Meijer SS, Catacutan D, Ajayi OC, Sileshi GW, Nieuwenhuis M (2014) The role of knowledge, attitudes and perceptions in the uptake of agricultural and agroforestry innovations among smallholder farmers in sub-Saharan Africa. Int $\mathbf{J}$ Agric Sustain 13:40-54. https://doi.org/10.1080/ 14735903.2014.912493

Metzel R, Montagnini F (2014) From farm to forest: factors associated with protecting and planting trees in a Panamanian agricultural landscape. Bois For Trop 322:3-15

Montagnini F, Ibrahim M, Murgueitio E (2013) Silvopastoral systems and climate change mitigation in Latin America. Bois For Trop 316:3-16

Nainggolan D, Termansen M, Reed MS, Cebollero ED, Hubacek K (2013) Farmer typology, future scenarios and the implications for ecosystem service provision: a case study from south-eastern Spain. Reg Environ Change 13:601-614. https://doi.org/10.1007/s10113-011-0261-6

Ochoa MWS, Härtl FH, Paul C, Knoke T (2019) Cropping systems are homogenized by off-farm income-empirical evidence from small-scale farming systems in dry forests of southern Ecuador. Land Use Policy 82:204-219. https:// doi.org/10.1016/j.landusepol.2018.11.025

Pannell DJ, Marshall GR, Barr N, Curtis A, Vanclay F, Wilkinson R (2006) Understanding and promoting adoption of conservation practices by rural landholders. Aust J Exp Agric 46:1407. https://doi.org/10.1071/EA05037

Pattanayak SK, Evan Mercer D, Sills E, Yang J-C (2003) Taking stock of agroforestry adoption studies. Agrofor Syst 57:173-186. https://doi.org/10.1023/A:1024809108210

Paul C, Weber M, Knoke T (2017) Agroforestry versus farm mosaic systems-comparing land-use efficiency, economic returns and risks under climate change effects. Sci Total Environ 587-588:22-35. https://doi.org/10.1016/j. scitotenv.2017.02.037

Perz SG, Walker RT, Caldas MM (2006) Beyond population and environment: household demographic life cycles and land use allocation among small farms in the Amazon. Hum Ecol 34:829-849. https://doi.org/10.1007/s10745-0069039-8

Riley J, Fielding WJ (2001) An illustrated review of some farmer participatory research techniques. JABES 6:5-18. https://doi.org/10.1198/108571101300325210

Romero C (2001) Extended lexicographic goal programming: a unifying approach. Omega 29:63-71
Schuchmann J (2011) A participatory survey on current integration of trees on farms and pastures within land use systems in the township of Tortí in Panama. Bachelor thesis, Technical University of Munich

Shrestha RK, Alavalapati JRR, Kalmbacher RS (2004) Exploring the potential for silvopasture adoption in southcentral Florida: an application of SWOT-AHP method. Agric Syst 81:185-199. https://doi.org/10.1016/j.agsy. 2003.09.004

Stewart TJ, Janssen R, van Herwijnen M (2004) A genetic algorithm approach to multiobjective land use planning. Comput Oper Res 31:2293-2313. https://doi.org/10.1016/ S0305-0548(03)00188-6

Torres B, Vasco C, Günter S, Knoke T (2018) Determinants of agricultural diversification in a hotspot area: evidence from colonist and indigenous communities in the Sumaco Biosphere Reserve, Ecuadorian Amazon. Sustainability 10:1432. https://doi.org/10.3390/su10051432

Tschakert P, Coomes OT, Potvin C (2007) Indigenous livelihoods, slash-and-burn agriculture, and carbon stocks in Eastern Panama. Ecol Econ 60:807-820. https://doi.org/ 10.1016/j.ecolecon.2006.02.001

Tsonkova P, Quinkenstein A, Böhm C, Freese D, Schaller E (2014) Ecosystem services assessment tool for agroforestry (ESAT-A): an approach to assess selected ecosystem services provided by alley cropping systems. Ecol Indic 45:285-299. https://doi.org/10.1016/j.ecolind.2014.04.024

Turnhout E, Bloomfield B, Hulme M, Vogel J, Wynne B (2012) Listen to the voices of experience. Nature 488:454-455. https://doi.org/10.1038/488454a

Uhde B, Heinrichs S, Stiehl CR, Ammer C, Müller-Using B, Knoke T (2017) Bringing ecosystem services into forest planning — can we optimize the composition of Chilean forests based on expert knowledge? For Ecol Manag 404:126-140. https://doi.org/10.1016/j.foreco.2017.08. 021

van der Plas F, Manning P, Soliveres S, Allan E, SchererLorenzen $\mathrm{M}$, Verheyen $\mathrm{K}$, Wirth $\mathrm{C}$, Zavala MA, Ampoorter E, Baeten L et al (2016) Biotic homogenization can decrease landscape-scale forest multifunctionality. Proc Natl Acad Sci USA 113:3557-3562. https://doi.org/ 10.1073/pnas.1517903113

Voinov A, Bousquet F (2010) Modelling with stakeholders. Environ Model Softw 25:1268-1281. https://doi.org/10. 1016/j.envsoft.2010.03.007

Walker WE, Lempert RJ, Kwakkel JH (2013) Deep uncertainty. In: Gass SI, Fu M (eds) Encyclopedia of operations research and management science. Springer US, Boston, pp 395-402

Wright SJ, Samaniego MJ (2008) Historical, demographic and economic correlates of land-use change in the Republic of Panama. Soc Ecol 13:17

Zabala A, García-Barrios L, Pascual U (2013) Understanding the role of livelihoods in the adoption of silvopasture in the tropical forest frontier. In: 15th international BIOECON conference, Cambridge, UK, 18-20 September 2013

Publisher's Note Springer Nature remains neutral with regard to jurisdictional claims in published maps and institutional affiliations. 